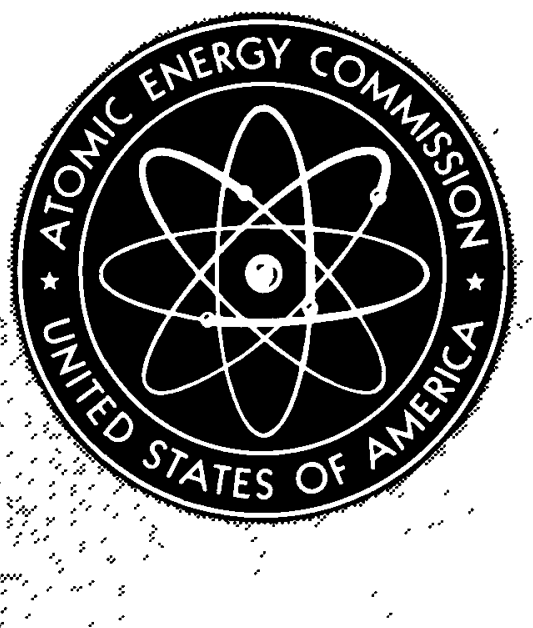

OR INS - 48

\title{
ELECTRODEPOSITION OF ACTINIDES AND LANTHANIDES
}

By

Stephen M. Kim

John E. Noakes

L. K. Akers

W. W. Miller

December 15, 1965

[DTIE Issuance Date]

Oak Ridge Institute of Nuclear Studies, Inc.

Oak Ridge, Tennessee

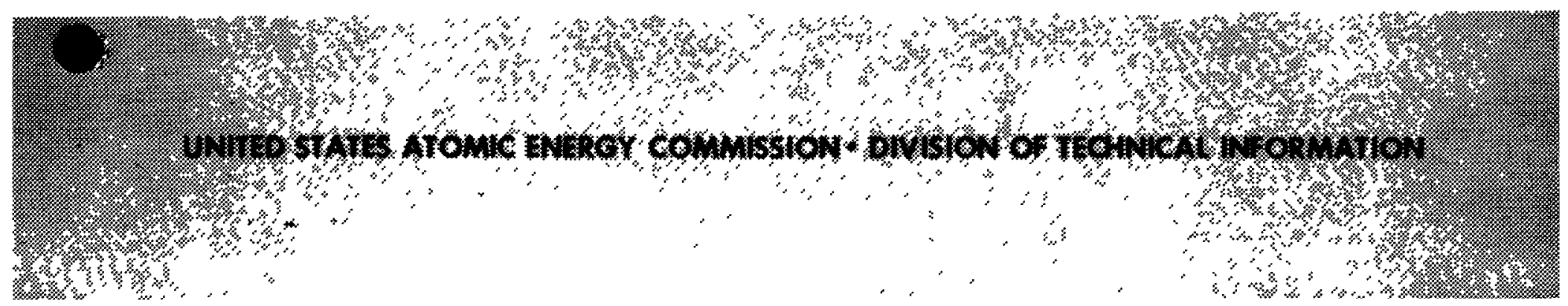




\section{LEG A L NOTICE}

This report was prepared as an account of Government sponsored work. Neither the United States, nor the Commission, nor any person acting on behalf of the Commission:

A. Makes any warranty or representation, expressed or implled, with respect to the accuracy, completeness, or usefulness of the information contained in this report, or that the use of any Information, apparatus, method, or process disclosed in this report may not infringe privately owned rights; or

B. Assumes any liabllities with respect to the use of, or for damages resulting from the use of any information, apparatus, method, or process disclosed in this report.

As used in the above, "person acting on behalf of the Commisaion" Includes any employee or contractor of the Commission, or employee of such contractor, to the extent that such employee or contractor of the Commission, or employee of such contractor prepares, disseminates, or provides access to, any information pursuant to his employment or contract with the Commission, or his employment with such contractor.

This report has been reproduced directly from the best available copy.

Printed in USA. Price $\$ 1.00$. Available from the Clearinghouse for Federal Scientific and Technical Information, $\mathrm{Na}$ tional Bureau of Standards, U. S. Department of Commerce, Springfield, Virginia 22151. 


\section{DISCLAIMER}

This report was prepared as an account of work sponsored by an agency of the United States Government. Neither the United States Government nor any agency Thereof, nor any of their employees, makes any warranty, express or implied, or assumes any legal liability or responsibility for the accuracy, completeness, or usefulness of any information, apparatus, product, or process disclosed, or represents that its use would not infringe privately owned rights. Reference herein to any specific commercial product, process, or service by trade name, trademark, manufacturer, or otherwise does not necessarily constitute or imply its endorsement, recommendation, or favoring by the United States Government or any agency thereof. The views and opinions of authors expressed herein do not necessarily state or reflect those of the United States Government or any agency thereof. 


\section{DISCLAIMER}

Portions of this document may be illegible in electronic image products. Images are produced from the best available original document. 
ORINS - 48

CHEMISTRY

(TID $-4500,46$ th. Ed.)

\section{ELECTRODEPOSITION OF ACTINIDES AND LANTHANIDES}

Stephen M. Kim, John E. Noakes, L. K. Akers, and W. W. Miller

Oak Ridge Institute of Nuclear Studies

Oak Ridge, Tennessee 


\begin{abstract}
A systematic study of the quantitative electrodeposition of thorium, protactinium, and uranium has been carried out for the preparation of thin film samples to be used in the field of nuclear spectral analysis. Under optimum conditions, yields of nearly $100 \%$ were realized with a reproducibility between samples of $2 \%$. The electrodeposition method, which has been developed, utilizes $95 \%$ ethanol as an electroplating solution with the electrodeposition being done on platinum metal.

A study on some lanthanides was also carried out using the method. Qualitative predictions of optimum conditions of the electrodeposition of trace amounts of other elements were made utilizing similarities in the known properties of elements, such as the solubility products of their compounds and their reduction potential.
\end{abstract}




\title{
ELECTRODEPOSITION OF ACTINIDES AND LANTHANIDES
}

\author{
Stephen M. Kim, John E. Noakes, L. K. Akers, and W. W. Miller* \\ Oak Ridge Institute of Nuclear Studies \\ Oak Ridge, Tennessee
}

I. INTRODUCTION

\section{A. Origin and Importance of Study}

Preparation of a thin film of radioactive material has many applications in nuclear chemistry and physics. Many investigators have been active in this field, and various methods have been used for the preparation of such samples. For simplicity and convenience, a number of researchers have employed electrodeposition as a means of preparation of uniform thin films. The thin film sample in this study refers to a sample whose thickness is so small that alpha radiation from the material will not be degraded in energy in escaping from the sample. Ideally, the thickness should be a mono-molecular layer of material.

Electrodeposition has been a technique for many decades, and many formulas for the electroplating can be found in publications. Since World War II, there has been an extensive amount of informative material published on this subject. However, duplication of results by other laboratories has been difficult, if not almost impossible, because of the ambiguity of stated conditions. The fact that one should take the empirical approach to determine the optimum condition for electrodeposition of an element is pointed out by Yaffe, ${ }^{1}$ Byrne and others. ${ }^{2}$

The first phase of this study, which was to determine the optimum conditions of electrodeposition for uranium, thorium, and protactinium, was started in connection with the geochronology group at Oak Ridge Institute of Nuclear Studies, Oak Ridge, Tennessee. Undistorted alpha spectra of these elements were needed for the calculation of an ocean sediment age. Many workers $3,4,5,6,7,8$ have prepared thin samples by the electrodeposition processes and have found, by the trial and error method, the conditions at which the deposition of an element is optimized. After many unsuccessful trials of duplication of reported methods, a new electrodepositing solution system was sought. The electrodepositing solution system should satisfy the following points:

1. The solution system should have ease of preparation.

2. The solution system should be free of radiochemical and trace metal contamination.

3. The solution system should reproduce the deposition yield and be easily duplicated by the other laboratories.

If the solution system satisfies the above requirements, it would simplify the laborious efforts of an investigator during the process of finding optimum conditions of electrodeposition of an element. Among the previously mentioned workers, only one postulation of electrodeposition process is cited and that is hydroxide precipitation on the cathode. Hydroxyl ions are formed by the reduction of water, and

\footnotetext{
* Chemistry Department, The Penn State University
} 
the hydroxyl ion would form an infinitesimal layer at the cathode during the electrodeposition process. The ionic species to be deposited migrate to the cathode, and form insoluble hydroxides which are absorbed on the cathodic surface. From this postulation, one assumes that the current is used for the formation of hydroxyl ions and one does not consider the possibility of consumption of current by the ionic species under study. At any rate, the current consumed by the ionic species is very small, compared with the fraction carried by the water. This postulation was deduced from the fact that hydroxides of some elements are very insoluble and the reduction potential of the element is high, so that the applied potential is less than the reduction potential of the element under study. However, there is no evidence cited by published works that the deposited material is the hydroxide of the ele ment under study, and no contradiction has been made of the postulation thus far.

One can always raise a question that there should be a reduction of the element in the solution at the cathode surface, if the cathode potential is more cathodic than the potential of the reduction reaction of metal species present. It seems that previous investigators have not considered this possibility in their publications. ${ }^{3,4,5,6,7,8}$ Therefore, merit exists in studying electrode reactions of the deposition process. This study will refer to the reduction process as an electro-reduction reaction and to the hydroxide formation process as an electro-precipitation reaction. The study should also yield a better understanding of electrodeposition reactions.

The second phase of the study was on some lanthanides. Lanthanides were chosen for studying relative behavior of electrodeposition of an element because these elements have similar properties. The study on lanthanides could yield a trend of the relationship between chemical properties and electrodeposition behavior of these elements. Any deviation from the general trend of behavior would give an investigator a possible indication of the electrodeposition mechanism.

Understanding of the process of electrodeposition will make possible reasonable predictions of the optimum condition for the deposition of an element on the basis of its known properties. By doing so, an investigator can save time and the tedious labor required for the determination by the trial and error method.

\section{B. Previous Related Studies}

The first uranium electrodeposition was carried out by Smith ${ }^{9}$ in 1898 on a platinum cathode from an acid solution of uranyl nitrate, but in the most widely used method at present, uranium is electroplated as a hydrous oxide film at a platinum cathode from an ammonium oxalate solution. ${ }^{5,7}$ Uranium also has been deposited on a platinum cathode from ammonium formate, ${ }^{10}$ from ammonium chloride, ${ }^{11}$ and from aqueous acidic solutions. ${ }^{12}$ Haissinsky ${ }^{13}$ also has studied the electrodeposition of actinide elements from ethanol, acetone, and water mixture. There are also studies carried out on uranium, using a cathode material other than platinum, notably on mercury. ${ }^{14}$

Cohen and Hull ${ }^{15}$ postulated that uranium forms an insoluble hydrous oxide by the following reaction in the electrolys is cell;

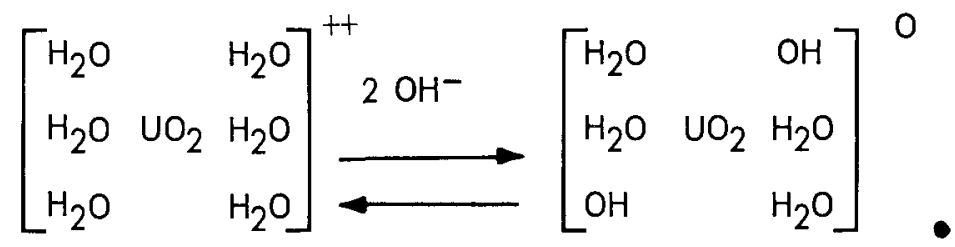


$\mathrm{Ko}^{6}$ pointed out that reduction of $\mathrm{H}^{+}$ions and oxidation of formate ion ehhance the possibility of metal hydroxide formation by decreasing the hydrogen ion concentration in the cell caused by the following electrode reactions:

$\begin{array}{ll}\begin{array}{l}\text { Cathode } \\ \text { Anode }\end{array} \mathrm{HCOO}^{+}+2 \mathrm{e}^{-} \longrightarrow \mathrm{H}_{2} \\ \mathrm{Net} & \mathrm{HCOO}^{-}+\mathrm{H}^{+} \longrightarrow \mathrm{H}^{+}+2 \mathrm{e}^{-} \\ \text {H } \mathrm{H}_{2}+\mathrm{CO}_{2}\end{array}$

These researchers do not consider the possibility of reduction of the uranium ion to its metallic form.

Thorium was first studied by $\mathrm{Toedt}^{8}$ in 1924 by deposition from hydrochloric acid solution. He suggested that thorium hydroxide was observed at the cathode surface. Thorium has also been electrodeposited from an ethanol-acetone-water mixture, ${ }^{16}$ from ammonium formate, ${ }^{10}$ from ammonium chloride, ${ }^{11}$ and from acidic solutions. ${ }^{12}$ Casto $^{7}$ also reported that thorium can be electrodeposited as thorium ferrocyanide precipitate, and $\mathrm{Ko}^{10}$ cited in his article the various methods of thorium precipitation such as fluosilicate and fluoborate from aqueous solution.

Protactinium electrochemistry in $\mathrm{HF}$ and $\mathrm{H}_{2} \mathrm{SO}_{4}$ solution has been studied ${ }^{17}$ and cathodic deposition potential by electrolysis of fluoride solution was found to be -1.2 volts with respect to the hydrogen electrode. ${ }^{18}$ Haissinsky ${ }^{13}$ has also studied electrodeposition behavior of protactinium.

The first lanthanide electrolysis in ethanol was reported by Hopkins and Audrieth ${ }^{19}$ on a mercury cathode in 1934, and these authors reported that a reduction process for the lanthanides prevails because of the formation of amalgam of these elements. Onstott $20,21,22,23$ also studied the behaviors of lanthanides in citrate media on mercury amalgam cathode, and he observed that there was not only amalgamation of lanthanides but also precipitate formation on the surface of the cathode. Kelman and others ${ }^{24}$ electroplated $\mathrm{EuCl}_{3}$ on aluminum foil from an ethanolic solution, and Milhelich and others ${ }^{25}$ made thin film of lanthanides from pyridine solution by electrodeposition on a platinum surface. Parker and Falk ${ }^{26}$ studied lanthanides electrodeposition from isopropyl alcohol solution, and they reported that the deposited compound possesses the same chemical formula as the chemical compound of the element which was introduced into the deposition cell. Therefore, they have named the process "molecular plating." Some researchers ${ }^{27,28}$ have employed the electrophoretic deposition method to prepare athin uniform sample of lanthanide oxide powder, and their recovery from the original solution ranges up to 80 per cent.

Previous stated studies give deposition yields ranging from 10 per cent to 100 per cent, the result for uranium being 100 per cent from ammonium formate solution, ${ }^{10}$ and by Samartseva ${ }^{12}$ for thorium of nearly 100 per cent from $1 \mathrm{~N} \mathrm{HNO}_{3}$ solution. Studies on lanthanides give different results from one electrolyte system to another, which range from 20 per cent to 80 per cent.

Most of those who have reported on the preparation of thin film samples were, in general, not interested in quantitative electrodeposition of an element. Their main interest has been only in the preparation of thin samples from a compound in order to study the $\alpha$ or $\beta$ spectra of the nuclide. Other investigators were electroplaters who were not interested in quantitative deposition. In any case, all were interested in the preparation of a thin sample with the expenditure of a minimum amount of time and effort. Up to the present, a correlation between an optimum condition of electrodeposition of an element and its properties has not been made, and a great deal of time is required to develop a process for the quantitative recovery of the sample material by electrodeposition. 


\section{PROCEDURE OF INVESTIGATION}

\section{A. Apparatus and Chemicals}

1. Apparatus

A jacketed cylindrical glass electrolysis cell was designed, as shown in Figure 1 . The temperature of the cell and electrolyte was controlled by circulating water through the jacket from a constant temperature water bath. The cell has a cross-section area of $6.2 \mathrm{~cm}^{2}$ which was used as a cathodic surface. A cold finger was placed on top of the cell to condense any evaporating ethanol during the electrodeposition. The electrode material used in this study is platinum in the form of a disc for the cathode and the form of a wire for the anode. A regulated power supply with voltage and current meters was used for the current source. To check the purity of the radioactive isotope produced, a gamma spectrum analysis was taken with a RCL multichannel analyzer. A determination of the amount of radioactive material deposited was made with a Sharp Low Beta proportional counter. The experimental arrangement is shown in Figure 2.

\section{Electrodeposition Cell and Condenser}
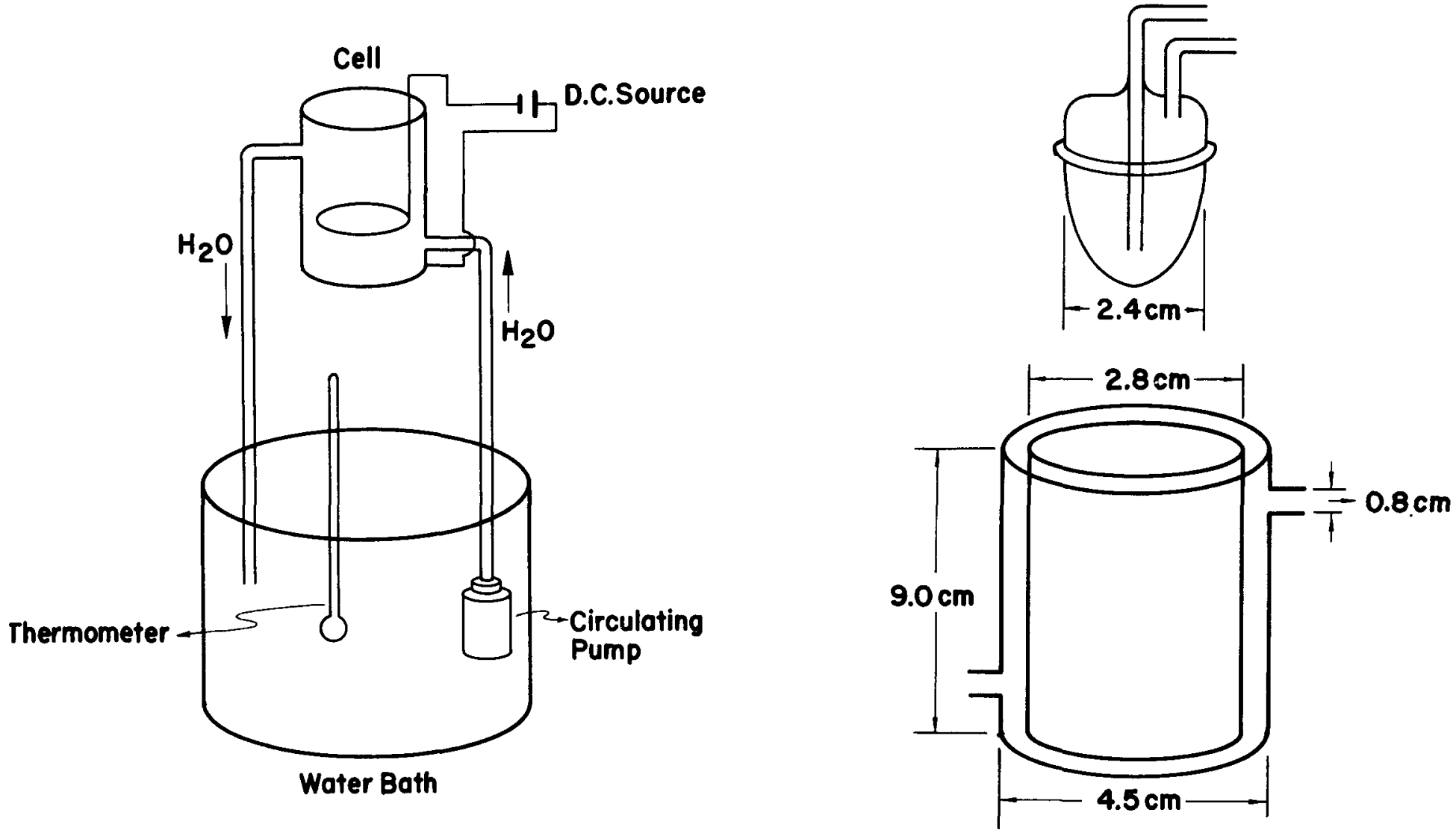

Fig. 2

Fig. 1 


\section{Chemicals}

All chemicals used in this study were reagent grade. The ethanol used in the study was 95\% pure. Each radioisotope was prepared in the following manner. The produced isotope was examined by gamma spectrometry for the purity of the sample, and it was found that there were no other radioactive species present. All the irradiation was done in Low Intensity Test Reactor at the Oak Ridge National Laboratory. The isotope produced and their half lives are shown in Table I.

Uranium: Uranium-236 was irradiated and purified by ion exchange technique. Each run of experiment contained five nanograms of uranium.

Thorium : Thorium-234 was separated from a Thorium-230 depleted uranyl nitrate solution by the ion exchange method. ${ }^{29}$ Carrier free thosium-234 was obtained by the eluting with a $8 \mathrm{~N}$ HCI solution from Dowex- 1 ion exchange column after the uranyl ion was washed with $6.8 \mathrm{~N}^{\mathrm{HNO}_{3}}$.

Protactinium: Protactinium-233 was obtained from Oak Ridge National Laboratory which was separated from irradiated thorium. This material is carrier free in $2 \mathrm{~N} \mathrm{H}_{2} \mathrm{SO}_{4}$ and $0.1 \mathrm{~N} \mathrm{HF}$ solution.

Lanthanum: Lanthanum nitrate was irradiated and dissolved in $2 \mathrm{~N} \mathrm{HCl}$. Ten micrograms of lanthanum were used for each deposition.

Cerium: $99.9 \%$ pure $\mathrm{CeO}_{2}$ was irradiated and dissolved in $2 \mathrm{~N} \mathrm{HCl}$. One hundred micrograms of $\mathrm{CeO}_{2}$ were used for each experiment.

Neodymium: $\mathrm{Nd}_{2} \mathrm{O}_{3}$ of $99.9 \%$ purity was irradiated and dissolved in $2 \mathrm{~N} \mathrm{HCl}$. In each experiment, one microgram of neodymium oxide was used.

Europium: Eu-152 was obtained from Oak Ridge National Laboratory as $\mathrm{EuCl}_{3}$ solution in $\mathrm{HCl}$. An aliquot of the Eu-152 solution was taken and evaporated to dryness, then it was taken up with $2 \mathrm{~N} \mathrm{HCl}$. 30 nanograms of Eu ${ }^{\mathrm{III}}$ ion were used for each experiment.

Terbium: $\mathrm{Tb}_{2} \mathrm{O}_{3}$ of $99.9 \%$ purity was irradiated and dissolved in $2 \mathrm{~N} \mathrm{HCl}$, and each deposition contained ten micrograms of terbium oxide.

Holmium: $\mathrm{Ho}_{2} \mathrm{O}_{3}$ of $99.9 \%$ purity was irradiated and dissolved in $2 \mathrm{~N} \mathrm{HCl}$, and each deposition sample contained ten micrograms of holmium oxide.

Thullium: $\mathrm{Tm}_{2} \mathrm{O}_{3}$ of $99.9 \%$ purity was irradiated and dissolved in $2 \mathrm{~N} \mathrm{HCl}$, and each sample contained one microgram of thullium oxide.

Ytterbium: $99.9 \%$ pure $\mathrm{Yb}_{2} \mathrm{O}_{3}$ was irradiated and dissolved in $2 \mathrm{~N} \mathrm{HCl}$, and each deposition sample contained one microgram of ytterbium oxide.

\section{B. Procedure}

During the process of duplication of the solution systems reported in publications, it was found that Haissinsky ${ }^{13}$ has used organic solution mixture. An organic solution system would produce a radiochemical inorganic metal free system. Therefore, initial study was carried out utilizing ethanol, water, and acetone system of Haissinsky. ${ }^{13}$ It was also found that the solution becomes hot and evaporates as the electrodeposition process progresses along. In order to keep the constant volume of the solution, one must add the solution as needed. In the process of adding the solution mixture, there is a possibility of altering the composition of the mixture. With this in mind, a single solution system was sought as the electroplating solution. Acetone was eliminated because of its low boiling point. Ethanol 
was used for the study and found satisfactory as the electrodepositing solution. Other alcohols, such as methanol and isopropanol also gave comparable yields.

\section{TABLE I}

\section{ISOTOPES USED IN THIS STUDY}

A. Prepared in Irradiation:

\begin{tabular}{|c|c|c|c|}
\hline Target material & Nuclear reaction & Isotope produced & Half life \\
\hline U-236 as nitrate & $n, \gamma$ & $U-237$ & $6.7 d$ \\
\hline $\mathrm{La}\left(\mathrm{NO}_{3}\right)_{3}$ & $n, \gamma$ & La-140 & $40.2 \mathrm{~h}$ \\
\hline $\mathrm{CeO}_{2}$ & $n, \gamma$ & $\mathrm{Ce}-141$ & $32.5 d$ \\
\hline $\mathrm{Nd}_{2} \mathrm{O}_{3}$ & $\mathrm{n}, \gamma$ & Nd- 147 & 11.10 \\
\hline $\mathrm{Tb}_{2} \mathrm{O}_{3}$ & $n, \gamma$ & $T b-160$ & $73 d$ \\
\hline $\mathrm{Ho}_{2} \mathrm{O}_{3}$ & $n, \gamma$ & Ho- 166 & $27.2 \mathrm{~h}$ \\
\hline $\mathrm{Tm}_{2} \mathrm{O}_{3}$ & $n, \gamma$ & $\mathrm{Tm}-170$ & $127 \mathrm{~d}$ \\
\hline $\mathrm{Yb}_{2} \mathrm{O}_{3}$ & $n, \gamma$ & Yb-175 & $4.2 d$ \\
\hline Th-232 & $n, \gamma$ & $\downarrow_{\mathrm{Pa}-233}^{\mathrm{Th}-233}$ & $\begin{array}{l}22.1 \mathrm{~m} \\
27.4 \mathrm{~d}\end{array}$ \\
\hline
\end{tabular}

B. Separated Chemically:

$\frac{\text { Isotope separated }}{\text { Th-234 }} \quad \frac{\text { Material used }}{\text { Uranyl nitrate }} \quad \frac{\text { Method used }}{\text { lon exchange }} \quad \frac{\text { Half life }}{24.1 \mathrm{~d}}$

C. Purchased Commercially:

$\begin{array}{llr}\text { Isotope } & \text { Firm } & \text { Half life } \\ \text { Eu-152 } & \text { Oak Ridge National Laboratory } & 13 \text { y }\end{array}$

Using 95\% ethanol, the first phase of this study was started. For each electrodeposition, the cell was assembled by placing a platinum cathode disc at the bottom of the cell with rubber cement. After the rubber cement had dried, a few milliliters of ethanol was added to see if there was a leak. Two hundred microliters of the radioisotope solution were added to be electroplated. More ethanol was 
added then to bring the total volume of the electrolyte to $20 \mathrm{ml}$. A platinum anode was placed $1.5 \mathrm{~cm}$ from the cathode surface and current was applied for the intended period. At the end of deposition, the current was turned off, and the solution was then removed. The current was turned off before removing the solution throughout this study as there was no dissolution of deposited material after the current was turned off. The platinum disc was flamed and counted for the yield of the experiment.

A systematic study of thorium, protactinium, and uranium electrodeposition was carried out for the determination of the optimum conditions. There are many variables for the determination of the optimum condition in electrode-position of an element. The variables studied in this work were the following: Current density, temperature of the solution, and duration of deposition. Other conditions were held constant.

The optimum condition of each parameter was studied by holding all other parameters constant and changing only the one under study. Amount of water or acid present in the cell would change conductance of the solution; therefore, fixed volume of tracers and the ir concentration were used throughout the study, these being $2 \mathrm{~N}$ in $\mathrm{HCl}$ and 200 microliters of the solution. The applied voltage was changed as the electrolysis proceeded, in order to maintain the constant current. The temperature of the cell was changed by circulating constant temperature water through the cell jacket. For the high temperature experiment, a cold condenser was placed on top of the cell to keep the constant volume.

The determination of the optimum conditions for an element electrodeposition requires a great deal of time and effort of an investigator. For each element, one must repeat the laborious procedure of finding the conditions suitable for quantitative electrodeposition. It would simplify the investigation, if one has some knowledge of relationship between chemical properties and electrodeposition behavior of an element.

The second phase of this study was to make some co-relation between the chemical properties and the electrodeposition behavior. Some lanthanides were chosen for this study. The conditions utilized were not the optimum conditions for the lanthanides but for the thorium electrodeposition; however, the study yielded a reasonable amount of deposition. These conditions were $150 \mathrm{~mA}$ current, one hour deposition period, and a solution temperature of $20 \pm 1^{\circ} \mathrm{C}$. The temperature effect of electrodeposition was studied on $\mathrm{Eu}$ and $\mathrm{Tb}$ in order to compare elements having only one stable oxidation state with elements with more than one stable state. The temperature of the cell was $50 \pm 3^{\circ} \mathrm{C}$ during the high temperature experiment.

It is possible that an anodic oxidation product may affect the electrodeposition process. The effect was studied as follows: The solution of ethanol and hydrochloric acid was electrolyzed for one hour to produce the anodic oxidation product, then the radioactive tracer, europium, was added. The electrolysis was carried out for one more hour, and the deposition yield was calculated.

If the element under study is reduced at the cathode, it will be possible to redissolve the element by reverse electrodeposition after normal electrodeposition. After the deposition yield was calculated, the deposition cell was constructed, using the same platinum disc. The current was reversely applied for one hour.

The $\mathrm{pH}$ of the solution system prior to and after electrodeposition were noted.

\section{EXPERIMENTAL RESULTS}

Results of the optimum conditions determination study for thorium, uranium, and protactinium electrodeposition are given in Tables II, III, and IV. The optimum conditions found during this study are shown in Table $\mathrm{V}$. 
Results of the lanthanide electrodeposition at applied current $150 \mathrm{~mA}$, deposition period of one hour, and solution temperature of $20^{\circ} \mathrm{C}$ and $50^{\circ} \mathrm{C}$ are given in Table VI.

The result of the electrodeposition, using the solution which was electrolyzed for one hour to see the effect of anodic oxidation product on europium, was found to be $49.2 \%$ yield, which is well in agreement with the result obtained previously. Striping study of deposited disc yielded that $72 \%$ of deposited material was re-dissolved into the solution when the polarity was reversed for one hour period. $\mathrm{pH}$ was changed during the experiment from 0.8 to 1.2 .

TABLE ||

\section{ELECTRODEPOSITION STUDY OF THORIUM}

Study of current at deposition period of $30 \mathrm{~min}$. and $20^{\circ} \mathrm{C}$ solution temperature

$\begin{array}{cc}\frac{\text { Current }}{50 \mathrm{~mA}} & \text { Yield } \\ 100 \mathrm{~mA} & 63 \% \\ 150 \mathrm{~mA} & 78 \% \\ 200 \mathrm{~mA} & 86 \% \\ & 82 \%\end{array}$

Study of deposition period at current $150 \mathrm{~mA}$ and $20^{\circ} \mathrm{C}$ solution temperature

$\begin{array}{ll}\text { Time } & \text { Yield } \\ 30 \mathrm{~min} . & 86 \% \\ 40 \mathrm{~min} . & 88 \% \\ 60 \mathrm{~min} . & 95 \% \\ 90 \mathrm{~min} . & 96 \%\end{array}$

Study of solution temperature at current $150 \mathrm{~mA}$ and $60 \mathrm{~min}$. period

\begin{tabular}{cc} 
Temperature & Yield \\
\hline $10^{\circ} \mathrm{C}$ & $90 \%$ \\
$20^{\circ} \mathrm{C}$ & $95 \%$ \\
$25^{\circ} \mathrm{C}$ & $99 \%$ \\
$30^{\circ} \mathrm{C}$ & $90 \%$ \\
$50^{\circ} \mathrm{C}$ & $80 \%$ \\
$70^{\circ} \mathrm{C}$ & $80 \%$ \\
$80^{\circ} \mathrm{C}$ & $86 \%$
\end{tabular}


TABLE III

\section{ELECTRODEPOSITION STUDY OF PROTACTINIUM}

Study of current of $30 \mathrm{~min}$. period and $70^{\circ} \mathrm{C}$ solution temperature

\begin{tabular}{ll} 
Current & Yield \\
\hline $100 \mathrm{~mA}$ & $28 \%$ \\
$150 \mathrm{~mA}$ & $39 \%$ \\
$200 \mathrm{~mA}$ & $68 \%$
\end{tabular}

Study of deposition period at $260 \mathrm{~mA}$ and $70^{\circ}$ solution temperature

\begin{tabular}{lc}
$\frac{\text { Time }}{30 \mathrm{~min} .}$ & Yield \\
\cline { 2 - 2 } $45 \mathrm{~min}$. & $68 \%$ \\
$60 \mathrm{~min}$. & $91 \%$ \\
& $98 \%$
\end{tabular}

Study of solution temperature at $200 \mathrm{~mA}$ current and $60 \mathrm{~min}$. period

\begin{tabular}{lc} 
Temperature & Yield \\
\hline $10^{\circ} \mathrm{C}$ & $55 \%$ \\
$25^{\circ} \mathrm{C}$ & $60 \%$ \\
$50^{\circ} \mathrm{C}$ & $75 \%$ \\
$60^{\circ} \mathrm{C}$ & $80 \%$ \\
$70^{\circ} \mathrm{C}$ & $99 \%$ \\
$80^{\circ} \mathrm{C}$ & $70 \%$
\end{tabular}


TABLE IV

\section{ELECTRODEPOSITION STUDY OF URANIUM}

Study of current at deposition time of $30 \mathrm{~min}$. and $20^{\circ} \mathrm{C}$ solution temperature

\begin{tabular}{cc} 
Current & Yield \\
\hline $50 \mathrm{~mA}$ & $11 \%$ \\
$100 \mathrm{~mA}$ & $46 \%$ \\
$150 \mathrm{~mA}$ & $51 \%$ \\
$200 \mathrm{~mA}$ & $49 \%$
\end{tabular}

Study of deposition time at current of $150 \mathrm{~mA}$ and at $20^{\circ} \mathrm{C}$ solution temperature

\begin{tabular}{lc}
$\frac{\text { Time }}{30 \mathrm{~min} .}$ & Yield \\
\hline $60 \mathrm{~min}$. & $51 \%$ \\
$90 \mathrm{~min}$. & $51 \%$ \\
$120 \mathrm{~min}$. & $67 \%$ \\
& $92 \%$
\end{tabular}

Study of temperature at current of $150 \mathrm{~mA}$ and $120 \mathrm{~min}$. period

\begin{tabular}{cc} 
Temperature & Yield \\
\hline $20^{\circ} \mathrm{C}$ & $92 \%$ \\
$50^{\circ} \mathrm{C}$ & $94 \%$ \\
$60^{\circ} \mathrm{C}$ & $97 \%$ \\
$70^{\circ} \mathrm{C}$ & $97 \%$ \\
$80^{\circ} \mathrm{C}$ & $94 \%$
\end{tabular}


TABLE V

OPTIMUM CONDITIONS FOR THORIUM, PROTACTINIUM, AND URANIUM ELECTRODEPOSITION

\begin{tabular}{|c|c|c|c|}
\hline Element & Applied Current & Deposition Period & $\begin{array}{c}\text { Solution } \\
\text { Temperature }\end{array}$ \\
\hline Th & $150 \mathrm{~mA}$ & $60 \mathrm{~min}$. & $25^{\circ} \mathrm{C}$ \\
\hline $\mathrm{Pa}$ & $200 \mathrm{~mA}$ & $60 \mathrm{~min}$. & $70^{\circ} \mathrm{C}$ \\
\hline$U$ & $150 \mathrm{~mA}$ & $120 \mathrm{~min}$. & $65^{\circ} \mathrm{C}$ \\
\hline
\end{tabular}

TABLE VI

ELECTRODEPOSITION OF LANTHANIDES

\begin{tabular}{|c|c|c|c|c|c|c|}
\hline \multicolumn{4}{|c|}{ Solution Temperature $20^{\circ} \mathrm{C}$} & \multicolumn{3}{|c|}{ Solution Temperature $50^{\circ} \mathrm{C}$} \\
\hline Element & $\begin{array}{l}\text { Applied } \\
\text { Initial }\end{array}$ & $\begin{array}{c}\text { Voltage } \\
\text { Final } \\
\end{array}$ & Yield* & $\begin{array}{l}\text { Applied } \\
\text { Initial }\end{array}$ & $\begin{array}{c}\text { Voltage } \\
\text { Final }\end{array}$ & $\begin{array}{l}50^{\circ} \mathrm{C} \\
\text { Yield }\end{array}$ \\
\hline La & $80 \mathrm{~V}$ & $100 \mathrm{~V}$ & $69 \pm 3 \%$ & & & \\
\hline $\mathrm{Ce}$ & $70 \mathrm{~V}$ & $90 \mathrm{~V}$ & $92 \pm 5 \%$ & & & \\
\hline $\mathrm{Nd}$ & $70 \mathrm{~V}$ & $100 \mathrm{~V}$ & $80 \pm 3 \%$ & & & \\
\hline Eu & $70 \mathrm{~V}$ & $100 \mathrm{~V}$ & $49 \pm 2 \%$ & $55 \mathrm{~V}$ & $70 \mathrm{~V}$ & $69 \pm 4 \%$ \\
\hline $\mathrm{Tb}$ & $70 \mathrm{~V}$ & $100 \mathrm{~V}$ & $76 \pm 3 \%$ & $55 \mathrm{~V}$ & $70 \mathrm{~V}$ & $75 \pm 6 \%$ \\
\hline $\mathrm{Ho}_{\mathrm{O}}$ & $70 \mathrm{~V}$ & $110 \mathrm{~V}$ & $77 \pm 8 \%$ & & & \\
\hline $\mathrm{Tm}$ & $70 \mathrm{~V}$ & $100 \mathrm{~V}$ & $81 \pm 4 \%$ & & & \\
\hline$Y b$ & $70 \mathrm{~V}$ & $110 \mathrm{~V}$ & $45 \pm 4 \%$ & & & \\
\hline
\end{tabular}

* Standard deviation calculated for five samples. 


\section{CONSIDERATION AND DISCUSSION}

The first phase of the study, which was to prepare a uniformly thin sample of thorium, protactinium, and uranium by electrodeposition, was achieved. The optimum conditions found are routinely applied at the Oak Ridge Institute of Nuclear Studies and Scripp Institute of Oceanography, La Jolla, California. ${ }^{30}$ During the application of the method to an ocean sediment sample, there was some diff iculty in the electrodeposition. It was suspected that some organic residue from ion exchange separation step was interferring, and the solution from the ion exchange column was treated with concentrated nitric acid several times. The residue was then taken up with hydrochloric acid for the electrodeposition. This treatment has yielded the same results as the data obtained with the tracers used in this experiment. It is not possible to produce less than 200 microliters of solution when one is processing a sediment sample. It was also found that an aliquot as large as 500 microliters in $0.1 \mathrm{~N} \mathrm{HCl}$ could be tolerated and still give results in the $70 \%$ deposition yield range. A sample spectrum of electrodeposited thorium is shown in Figure 3.

The electrodeposition process of an element has many variables to be considered. These are applied potential, current density, shape and size of electrodes, agitation of solution, temperature of the solution, nature of electrode and electrolyte, distance between the electrodes, volume of electrolyte, and duration of electrodeposition. The above variables, of course, have some relation to each other, and the change of one would affect another in some cases. For example, the change of the applied current in this system would change the applied potential which would, in turn, affect the reduction

\section{Alpha Spectrum-Sample \# 72 68-Hour Count-Compeche Oölite 30 Jun - 3 Jul 1963}

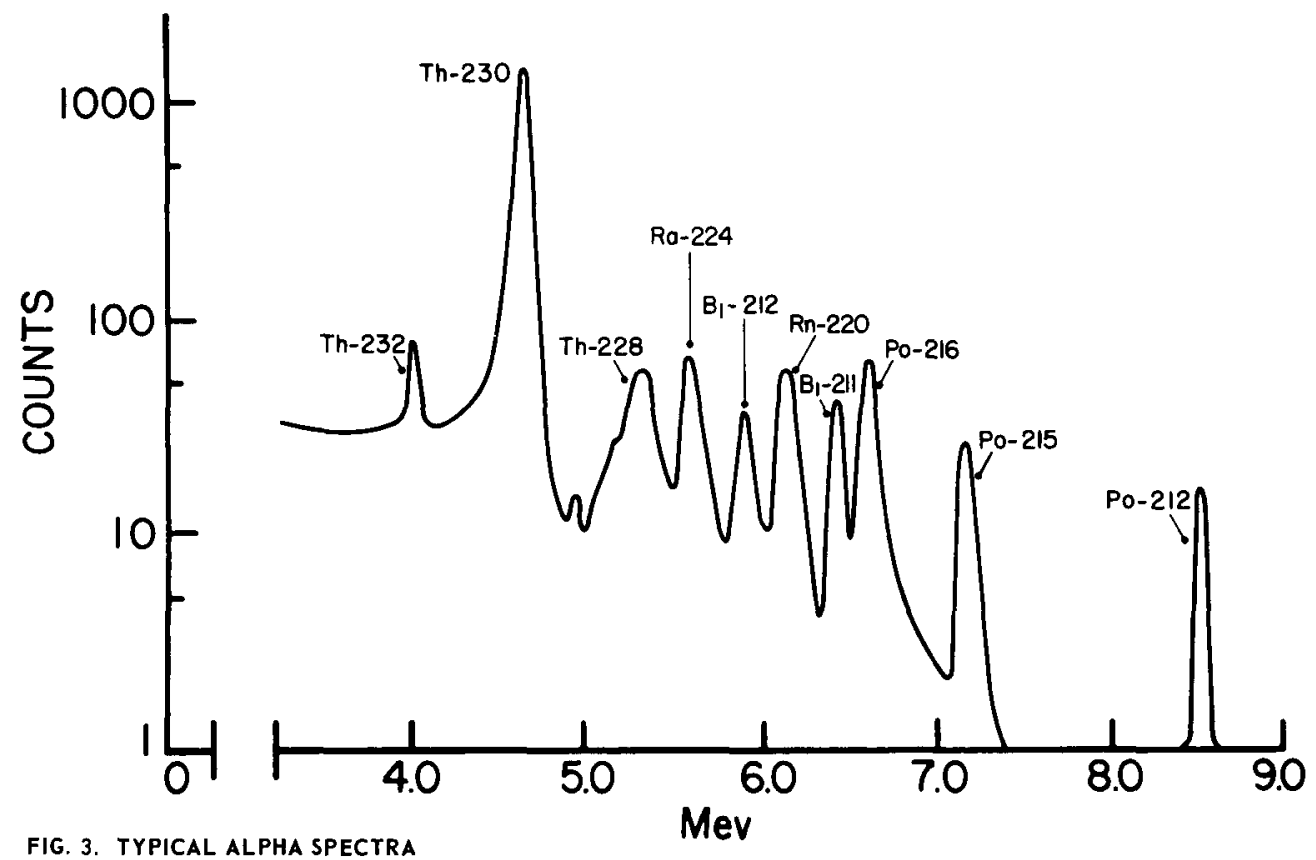


potentral. In order to obtain the optimum condition of an element for the electrodeposition, one should study all these variables for the determination process. In this study, the factors varied were applied current, duration of deposition, and temperature of the solution holding other factors constant.

During electrodeposition, more than one reaction is possible in the electrolysis cell. These are electrolysis of the electrolyte employed, and reduction of the element present. In the system utilized in this study, the following reactions are possible at the cathode:

1. Reduction of $\mathrm{H}^{+}$ion introduced

2 Reduction of the ionic species of element introduced

One should note that it is possible to have reduction of the element as well as the formation of insoluble hydroxide. Therefore, one could postulate that an electrodeposition process is a simultaneous process of insoluble hydroxide formation and reduction processes, varying only a fraction of these two reactions according to the element. One element could have hydroxide formation as the major deposition process, and the other may have reduction process as the major process, or both reactions at the equal fractions.

If a fixed amount of current is supplied to an electrolysis cell, there would be some deposition taking place. This deposit is caused by either process or by both processes simultaneously, and would vary according to the property of the element. Whatever the process of deposition may be, the amount of deposit, yield, indicates how much of the element under study reacted; therefore, the yield is the over-all measure of the reaction of the element at the cathode.

If an element undergoes deposition process chiefly by electro-precipitation, the smaller the solubility of hydroxide, the larger the amount of deposit obtained, and if deposition process is chiefly by slectro-reduction, the deposited amount would be somewhat affected by the reduction potential. If both processes are possible, the following reactions may happen on the cathode of the electrolysis cell for the deposition:

1. Formation of insoluble hydroxide

2. Reduction of element to a stable intermediate oxidation state

3. Reduction of ionic species to metallic state.

If only one reaction is the major reaction, any other competing reaction which hinders the major reaction would alter the amount of deposit. For example, if reaction (1) is the major process, any reaction at the cathode, which hinders the formation of insoluble hydroxide, would decrease the amount of deposit. If the condition of electrodeposition were changed from one condition to another, the amount of deposit would change according to the effect of the changed factor to the above three reactions. The temperature change would increase the rate of reduction reaction because of resistance and diffusion rate change, and would alter the solubility product of hydroxide according to the temperature coefficient of the compound. The solubility product of an insoluble hydroxide could be thought to have, in general, positive temperature coefficient.

The second phase of the study was done on the lanthanide to investigate correlation between chemical properties and the electrodeposition behavior. The chemical properties of lanthanides are given in Table VII. This table shows their possible stable oxidation states, solubility products of their hydroxides, and the reduction potentials of trivalent ions to the metallic states. All the lanthanides studied have reduction potential between 2.3 volts and 2.5 volts, and the solubility products vary from $10^{-19}$ to $10^{-24}$. According to solubility products and reduction potentials, the electrodeposition yield of these elements would have a trend of increase as the atomic number of the element increases, caused by 
less cathodic behavior of reduction potential and decrease of solubility product in that trend, assuming there are no other variables involved.

TABLE VII

\section{REDUCTION POTENTIALS AND SOLUBILITY PRODUCTS OF LANTHANIDES USED IN THIS STUDY}

\begin{tabular}{|c|c|c|c|}
\hline Element & Stable Oxidation State & $E^{\circ}$ for III States* & $\mathrm{K}_{\mathrm{sp}}$ for $\operatorname{Ln}(\mathrm{OH})_{3}{ }^{*}$ \\
\hline La & 3 & 2.52 & $1.0 \times 10^{-19}$ \\
\hline $\mathrm{Ce}$ & 3,4 & 2.48 & $1.5 \times 10^{-20}$ \\
\hline Nd & 3 & 2.44 & $1.9 \times 10^{-21}$ \\
\hline$E_{\mu}$ & 2,3 & 2.41 & $3.4 \times 10^{-22}$ \\
\hline $\mathrm{Tb}$ & 3 & 2.39 & $2.0 \times 10^{-22}$ \\
\hline Ho & 3 & 2.32 & $5 \times 10^{-23}$ \\
\hline$T m$ & 3 & 2.28 & $3.3 \times 10^{-24}$ \\
\hline $\mathrm{Yb}$ & 2,3 & 2.27 & $2.9 \times 10^{-24}$ \\
\hline
\end{tabular}

* Values from Latimer, Wendell M., The Oxidation States of the Elements and Their Potentials in Aqueous Solutions, Prentıce-Hall, N.Y. 1952

Considering these properties, one could group lanthanides in two groups according to their stable oxidation states, Group I being the elements with only one table oxidation state, and Group II being the elements with more than one stable oxidation state. La, Nd, Tb, Ho, and Tm fall into Group I and Eu and $\mathrm{Yb}$ fall into Group II. If all the lanthanides have only one stable oxidation state, the electrodeposition yield of these elements would be about the same, because of their similarity of chemical properties. However, Group II elements, which have more than one stable oxidation state, would behave differently from the elements with only one stable oxidation state during the electrodeposition process. The electrodeposition process of these elements would possibly take the following path:

1. Hydroxide formation of trivalent ion

2. Hydroxide formation of divalent ion after reduction of trivalent ion to divalent ion

3. Stepwise reduction of trivalent ion to metallic state.

If the postulation of only hydroxide formation is correct, one has to eliminate the possibility of reaction (3), reduction of ion to metallic state. Then the yield of these elements, Eu and Yb, would depend on the solubility products of divalent hydroxides. There is no reported values of the solubility products of these hydroxides, but it could be assumed that the solubility of these hydroxides is the same as that of $\mathrm{Ba}(\mathrm{OH})_{2}$, considering ionic size and chemical properties. From the above assumption, one could predict that Eu and $\mathrm{Yb}$ deposition yields would be lower than those of Group I elements because their reduction 
potentials are not too large $-\mathrm{Eu}^{+++}+\mathrm{e} \rightarrow \mathrm{Eu}^{++} 0.43$ volts, $\mathrm{Yb}^{\mathrm{f++}}+\mathrm{e}+\rightarrow \mathrm{Yb}^{++} 0.578$ volts. The experimental data shows that the yields of $\mathrm{Eu}$ and $\mathrm{Yb}$ deposition are considerably lower than those of Group I.

Even though the experimental data agree with the prediction, the possibility of reduction reaction is not completely eliminated because there is no experimental results published so far to confirm the postulation. If the deposit is caused by the electro-reduction process, it would be possible to re-dissolve by reversing the polarity of electrodes, while electro-precipitation deposit would not be easily redissolved. The data from this study on $\mathrm{Eu}$ indicates that the deposit could be redissolved by reverse electrodeposition. On the other hand, Onsttot $20,21,22,23$ reported that he was able to amalgamate lanthanides into a lithium amalgam cathode. These reports indicate that lanthanides could be reduced. Almagio and others ${ }^{31,32}$ have investigated lanthanides polarography in ethanolic medium and reported that they have observed two waves for $\mathrm{Eu}$ and $\mathrm{Yb}$ and one wave for the other elements studied in this study. These reports are clear indication of the presence of reduction reaction in the ethanolic system. Therefore, Eu and $\mathrm{Yb}$ could take all three paths mentioned during the electrodeposition process.

The deposition temperature was varied for Eu and Tb study. Amount of deposit was increased for $\mathrm{Eu}$ and not for $\mathrm{Tb}$. Increase of Eu yield indicates that some reaction is favored by the higher temperature. Whatever the process may be for the deposition, most of the current was carried by the electrolyte instead of the element to be plated. The amount of current carried by the element during the deposition process is less than 400 parts per million, assuming ten micrograms of a lanthanide element is present in the cell and all of the amount present is reduced. (See Appendix I.) Therefore, in the system studied, one could assume that the same amount of hydrogen was produced at the cathode, leaving the same amount of $\mathrm{OH}^{-}$ion at the different temperatures. If fixed amount of $\mathrm{OH}^{-}$ion is generated at the cathode, the yield should not vary with the temperature change of the electrolyte. The experimental data suggest that the amount of current carried by the ions to be deposited is increased with temperature increase in the case of $\mathrm{Eu}$.

The electrodeposition cell being well-stirred during the deposition process, the anode reaction needs to be considered. Dony-Henault, ${ }^{33}$ and Maroe and Lejeune ${ }^{34}$ studied anodic reaction of ethanol and reported that oxidation products are acetic acid and acetaldehyde. The amount of these products being the same for each deposition experiment, the effect from these products should be consistent. The effect of the anodic product was investigated in this study and it was found that there was no alteration of the yield by the product.

Cerium electrodeposition yield was very high and did not follow any trend of the other lanthanides. This could be explained by the concentration of cerium in the cell. There was a factor of ten between cerium concentration and other lanthanide concentration. The previous works ${ }^{12,23}$ reported that deposition yield is higher with the higher concentration of metallic ion to be plated.

\section{SUMMARY AND CONCLUSION}

\section{A. Summary and Conclusion}

Uniformly thin radioactive sources are needed for alpha and beta spectrometry and for absolute disintegration rate determinations of alpha and beta emitters. Thin sources of $T h, U$, and Pa are needed in geochronology of an ocean sediment. An electrodeposition system of these elements, which is reproducible by other laboratories, was sought for preparation of the sources. The electrodeposition method which has been developed in this study, utilizes $95 \%$ ethanol as an electrodeposition being done on 
platinum metal. A new jacketed electrodeposition cell was designed. Optimum conditions for electrodeposition of the above mentioned elements have been determined. The parameters studied were applied current, period of electrodeposition, and temperature of the solution holding all the others constant. Optimum conditions for electrodeposition of these elements are given in Table V. This method was found to be reproducible by other laboratories. ${ }^{30}$

Study on some lanthanides in the system mentioned was carried out. This phase of study was to investigate the prediction on the trend of deposition yield, considering the reduction potentials and the solubility products. It was found that $\mathrm{Eu}$ and $\mathrm{Yb}$ yields were lower than other lanthanides as predicted. At the present, only one postulation on electrodeposition mechanism, electroprecipitation process, is reported in the literature. Possibility of electroprediction reaction was studied and it was found that electroreduction reaction is possible.

From this study and reported works on electrochemistry of lanthanides, it is evident that the electrodeposition mechanism of sub-microgram quantity is a simultaneous process of electroprecipitation and electropreduction.

General grouping and qualitative prediction for the electrodeposition could be made according to elements. They could be grouped as electroreduction dominant or electroprecipitation dominant. Electroreduction dominant elements should be electrodeposited at higher temperature for faster reduction rate and higher current for more cathodic potential, and electroprecipitation dominant elements should be deposited at room temperature and moderate current. The optimum conditions obtained for Th, U, and $\mathrm{Pa}$ could be explained by the above prediction. Thorium would be classified as an electroprecipitation dominant and protactinium an electroreduction dominant. For electroreduction dominant process, the applied cathodic potential affects the rate of reduction, and this would be compared from the optimum, condition determination of $\mathrm{Th}$ and $\mathrm{Pa}$. Pa yielded a higher yield at $200 \mathrm{~mA}$ current and higher temperature than $\mathrm{Th}$, whereas, Th yielded at $150 \mathrm{~mA}$ and lower temperature. Uranium optimum conditions are somewhat intermediate between $\mathrm{Th}$ and $\mathrm{Pa}$. As shown in Table VIII, $\mathrm{U}$ has to reduce to positive 4 state in order to be electroprecipitated. Therefore, $U$ electrodeposition could be a stepwise process of electroreduction and electroprecipitation.

\section{B. Suggestion for Further Studies}

Lanthanide elements are often used in beta spectrometry. Therefore, the possibility of preparing a film sample of lanthanides should be studied. These investigators have done a preliminary study, using copper backed nickel foil as cathode material, and found satisfactory results.

TABLE VIII

PROPERTIES OF URANIUM, THORIUM, AND PROTACTINIUM

\begin{tabular}{|c|c|c|c|}
\hline Element & Stable Oxidation States & Reduction Potential & $K s p$ for $M(O H)_{n}$ \\
\hline Th & 4 & 1.90 & $10^{-39}$ \\
\hline $\mathrm{Pa}$ & 5 & 1.2 & soluble $\mathrm{F}^{-}$complex \\
\hline \multirow[t]{2}{*}{$U$} & 6,4 & $U^{+6}$ to $U^{+4} 0.62$ & soluble \\
\hline & & $U^{+4}$ to $U^{0} \quad 4.31$ & $10^{-45} \mathrm{U}(\mathrm{OH})_{4}$ \\
\hline
\end{tabular}




\section{BIBLIOGRAPHY}

1. Yaffe, L., Annual Rev. Nucl Sc1., 12, 153 (1962)

2. Bryne, J. T., Roger, L. B., and Griess, J. C., Jr. J. Electrochem. Soc., 98, 452 (1951)

3. Harvey, B. G., Introduction to Nuclear Physics and Chemistry, Prentice-Hall, Inc., Englewood Cliffs, N.J., 1962

4. Choppın, G. R., Experımental Nuclear Chemıstry, Prentıce-Hall, Inc., Englewood Clıffs, N.J., 1961

5. Hufford, D. L. and Scott, B. F., Paper 16.I IN: The Transuranium Elements, Part II edited by G. T. Seaborg, J. J. Katz and W. M. Manning, New York, McGraw-Hı1l, 1949. (National Nuclear Energy Series IV-14B) PP. 1149-1184

6. Ko, Roy, Nucleonics, 14, 7, 74 (1956)

7. Casto, C C., Chapter 23 IN: Analytıcal Chemistry of the Manhattan Project, edıted by C. J. Rodden, et al., New York, McGraw-Hill, 1950, (Natıonal Nuclear Energy Serıes, VIII-I) pP. $511-536$

8. Todt, F., Z. Physık Chem., 113, 329 (1924)

9. Smith, E. F., J. Am. Chem. Soc., 20, 279 (1898)

10 Ko, Roy, Nucleonics, 15, 1, 72 (1957)

11. Chatham-Strode, A., Private communication

12. Samartseva, A. G., IN: Transactıons of the All-Union Scientific Technical Conference on the Use of Radioactive and Stable Isotopes and Radiation in the National Economy and in Science, April 4-12, 1957. Isotopes and Radiation in Chemistry. English translation: AEC-tr-4497, pp. 400-410

13. Haıssinsky, M., Electrochimie des Substances Radioactives et des Solutions Extremement Diluees, Hermann and Cie, Paris, 1946

14. Russell, A. S., Nature, 127, 273 (1931)

15. Hull, D. E. and Cohen, B, MDDC-387 (1944)

16. Cotelle, S. and Haissinsky, M., Comp. rend. 206, 1644 (1938)

17. Bouissieres, G., J. Phys. et la Radium, 8, 2, 72 (1941)

18. Ferradinı, C., J. Chem. Phys., 53, 714 (1956)

19. Hopkıns, B. S. and Audrieth, L. F., Trans. Electrochem Soc., 66, 135 (1934)

20. Onstott, E. I., J. Am. Chem. Soc , 77, 2129 (1955)

21. Onstott, E. I., J. Am. Chem. Soc., 81, 4451 (1959)

22. Onstott, E. I., Anal. Chem. 33, 1470 (1961) 
23. Onstott, E. I., Inorg. Chem. 2, 967 (1963)

24. Kelman, V. M., Romanov, V. A., Metskhvarishvili, R. Ya., and Kelyunov, V. A., Nucl. Phys. 2, $395(1956 / 57)$

25. Mihelich, J.W., Ward, T. J., and Jacob, K. P., Phys. Rev., 103, 1285 (1956)

26. Parker, W. and Falk, R., Nucl. Instr. Methods, 16, 355 (1956)

27. Cranston, F. P., Jr. and McCreary, W. J., Rev. Sci. Instr., 27, 973 (1956)

28. Bjornholm, S., Dam, P. H., Nordby, H., and Poulsen, N. O. R., Nucl. Instr. Methods, 5, 196 (1959)

29. Noakes, J. E. and Supernaw, I. R., Private communication

30. Goldburg, E., Private communication

31. Almagro, J., Almagro, V., and Sancho, J., Anales de Fisica y Quimica, 58, 203 (1962)

32. Almagro, J., Almagro, V., and Sancho, J., Anales de Fisica y Quimica, 58, 459 (1962)

33. Dony-Hendult O., Zeit fur Elektrochem., 6, 533 (1900)

34. Marie, C. and Lajeune, G., Compt. rend, 137, 343 (1928)

\section{APPENDIX I}

Current $1 \mathrm{hr}$. at $150 \mathrm{~mA}$

$$
\begin{aligned}
& .15 \mathrm{~A} \times 3600 \mathrm{sec},=540 \mathrm{coul} \text {. }
\end{aligned}
$$

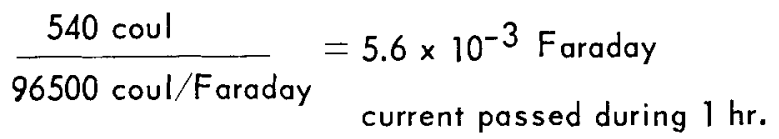

$$
\begin{aligned}
& \text { Current required to reduce } 10 \mathrm{ugm} \text { of a lanthanide } \\
& \frac{10 \times 10^{-6} \mathrm{gm}}{140 \mathrm{gm} / \mathrm{mole}}=7.15 \times 10^{-8} \text { moles } \\
& 7.15 \times 10^{-8} \text { mole } \times 3 \text { Faraday } / \text { mole }=2.15 \times 10^{-7} \text { Faraday } \\
& =21.5 \times 10^{-8} \text { Faraday } \\
& \begin{aligned}
\frac{21.5 \times 10^{-8}}{5.6 \times 10^{-3}} & =3.8 \times 10^{-5} \\
& =38 \times 10^{-6} \\
& =38 \text { p.p.m. }
\end{aligned}
\end{aligned}
$$

